\title{
IMPLEMENTASI FUZZY LOGIC DALAM SISTEM PAKAR UNTUK MENDETEKSI PENYAKIT KANKER SERVIKS
}

\author{
Siti Rochana ${ }^{1)}$, Andriani $\mathrm{KKW}^{2)}$, Yustina Retno Wahyu Utami ${ }^{3)}$ \\ 1), 2), 3) Program Studi Teknik Informatika, STMIK Sinar Nusantara Surakarta \\ 1), rochana.siti91@ gmail.com, ${ }^{2)}$,andrianikkw@yahoo.com, ${ }^{3)}$ yustina.retno@ gmail.om
}

\begin{abstract}
Cervical cancer is one of the most frequent cancer in women with the incidence and death rate from cervical cancer is quite high and is expected to continue to rise. This research will be discussed how to detect cervical cancer by implementing fuzzy logic. Fuzzy logic used is fuzzy Tsukamoto. The input parameters in the form of symptoms such as bleeding, vaginal discharge, pelvic pain, weight loss, and bladder pain. Based on 10 cases tested, there were 8 cases properly, so that the system test results by $80 \%$.

Keyword: Cervical Cancer, Fuzzy Logic, Fuzzy Inference System, Tsukamoto.
\end{abstract}

\section{PENDAHULUAN}

Kanker serviks atau kanker leher rahim merupakan salah satu kanker yang paling sering menyerang wanita dan menjadi ancaman berbahaya bagi para wanita diseluruh dunia. Angka kejadian dan tingkat kematian akibat kanker serviks cukup tinggi dan diperkirakan akan terus meningkat. Kanker serviks adalah kanker yang terjadi pada organ reproduksi wanita. Penyakit ini terjadi pada wanita usia reproduktif antara 20-30 tahun. Berdasarkan data Badan Kesehatan Dunia (WHO), saat ini penyakit kanker serviks menempati peringkat teratas di dunia dari beberapa kanker yang menyebabkan kematian bagi para perempuan. (Novel, dkk, 2010).

Untuk menjadikan masyarakat lebih terampil mengetahui gejala-gejala penyakit kanker serviks, serta memudahkan tanpa harus merasa risih saat memeriksakan diri ke pusat pelayanan kesehatan, maka aplikasi ini dibangun yang dapat berfungsi layaknya seorang ahli.

Metode yang akan digunakan dalam sistem pakar ini adalah logika fuzzy. Fuzzy dinyatakan dalam derajat dari suatu keanggotaan dan derajat dari kebenaran. Logika fuzzy yang digunakan adalah sistem inferensi fuzzy Tsukamoto karena metode ini menggunakan aplikasi nilai monoton. Input yang dibutuhkan adalah gejala-gejala yang dialami oleh penderita, kemudian akan diproses menggunakan kaidah produksi (IF-THEN). Output hasil inferensi dari tiap-tiap aturan diberikan secara tegas (crisp) berdasarkan $\alpha$-predikat (fire strength) yang diperoleh pada setiap aturan fuzzy untuk setiap penyakit (Kusumadewi \& Purnomo, 2010). Pada penelitian ini, akan dicoba untuk membuat aplikasi diagnosa penyakit kanker serviks menggunakan FIS Tsukamoto berdasarkan gejala-gejala tertentu.

\section{METODE PENELITIAN}

\subsection{Metode Pengumpulan Data}

Metode pengumpulan data yang digunakan dalam aplikasi deteksi penyakit kanker serviks ini antara lain: 
1. Metode literatur

Metode yang dilakukan oleh penulis dengan mempelajari berbagai literatur yan berhubungan dengan pembuatan skripsi penulis yang berkaitan dengan teori logika fuzzy dan FIS Tsukamoto.

2. Metode wawancara

Pengumpulan data dengan cara wawancara ini dilakukan dengan dokter ahli (dr. Supanji Raharja SpOG). wawancara yang dilakukan lebih menitikberatkan pada deskripsi penyakit kanker serviks, faktor penyebab kanker serviks, gejala-gejala adanya kanker serviks dan cara pencegahan kanker serviks. Hasil akhir dari diagnosa sistem akan dibandingkan dengan hasil diagnosa dengan pakar.

\section{TINJAUAN PUSTAKA}

\subsection{Gambaran Tentang Kanker Serviks}

Kanker serviks adalah kanker yang terjadai pada organ reproduksi wanita. Penyakit ini terjadi pada wanita usia reproduktif antara 20-30 tahun (FKUI, 2002). Pada umumnya kanker serviks disebabkan oleh infeksi Human Papiloma Virus $(H P V)$ biasanya tanpa disertai gejala sehingga orang tak menyadari kalau dirinya mengidap penyakit kanker serviks. Penelitian membuktikan lebih dari 90\% dari kanker serviks berasal dari sel epitel yang melapisi serviks dan $10 \%$ sisanya berasal dari sel kelenjar penghasil lendir pada saluran serviks yang menuju uterus (Novel, dkk, 2010).

\subsection{Sistem Pakar}

Sistem Pakar merupakan cabang dari kecerdasan buatan (Artificial Intellegence) yang cukup tua karena sistwm ini mulai dikembangkan pada pertengahan 1960. Sistem pakar berasal dari istilah knowledge base expert system (Sutojo, Edy, \& Suhartono, Kecerdasan Buatan, 2011).

Sistem Pakar merupakan program komputer yang menangani masalah dunia nyata masalah yang kompleks yang membutuhkan interpretasi pakar (Siswanto, 2010).

\subsection{Logika Fuzzy}

Dasar logika fuzzy adalah teori himpunan fuzzy. Pada teori himpunan fuzzy, peranan derajat keanggotaan sebagai penentu keberadaan elemen dalam suatu himpunan sangatlah penting. Nilai keanggotaan atau derajat keanggotaan atau membership function menjadi ciri utama dari penalaran dengan logika fuzzy tersebut. Logika fuzzy dapat dianggap sebagai kotak hitam yang menghubungkan antara ruang input menuju ruang output. Kotak hitam tersebut berisi cara atau metode yang dapat digunakan untuk mengolah data input menjadi output dalam bentuk informasi yang baik (Kusumadewi \& Purnomo, 2010).

\subsection{Fungsi Keanggotaan}

Fungsi keanggotaan (membership function) adalah suatu kurva yang menunjukkan pemetaaan titik-titik input data kedalam nilai keanggotaannya (sering disebut dengan derajat keanggotaan) yang memiliki interval antara 0 sampai 1. 
Fungsi keanggotaan dapat dibuat kedalam beberapa bentuk kurva diantaranya;

1) Representasi Linier

Pada representasi linier, permukaan digambarkan sebagai suatu garis lurus. Bentuk ini paling sederhana dan menjadi pilihan yang baik untuk mendekati suatu konsep yang kurang jelas.

Ada 2 kemungkinan keadaan himpunan fuzzy yang linier. Pertama, kenaikan himpunan dimulai pada nlai dominan yang memiliki derajat keanggotaan nol [0] bergerak kekanan menuju ke nilai domain yang memiliki derajat keanggotaan lebih tinggi seperti yang tergambar pada gambar 1 .

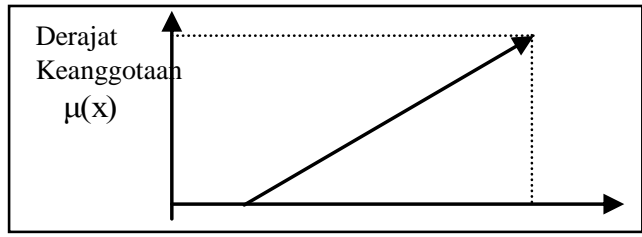

Gambar 1. Derajat keanggotaan

Fungsi keanggotaan :

$\mu(x)=\left\{\begin{array}{lc}0 ; & x \leq a \\ (x-a) /(b-a) ; & a \leq x \leq b \\ 1 ; & x \geq b\end{array}\right.$

Kedua, merupakan kebalikan yang pertama. Garis lurus dimulai dari nilai domain dengan derajat keanggotaan tertinggi pada sisi kiri, kemudian bergerak menurun ke nilai domain yang memiliki derajat keanggotaan lebih rendah atau sering disebut dengan kurva linear turun.

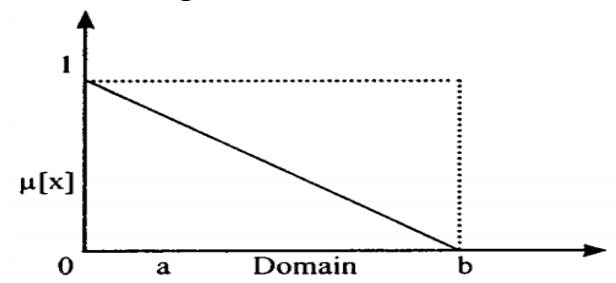

Gambar 2. Representasi Linear Turun

Fungsi keanggotaan :

$$
\mu(x)= \begin{cases}(b-x) /(b-a) ; & a \leq x \leq b \\ 0 ; & x \geq b\end{cases}
$$

2) Representasi Kurva Segitiga

Kurva segitiga pada dasarnya merupakan gabungan antara 2 garis (linier seperti terlihat pada gambar 3. 


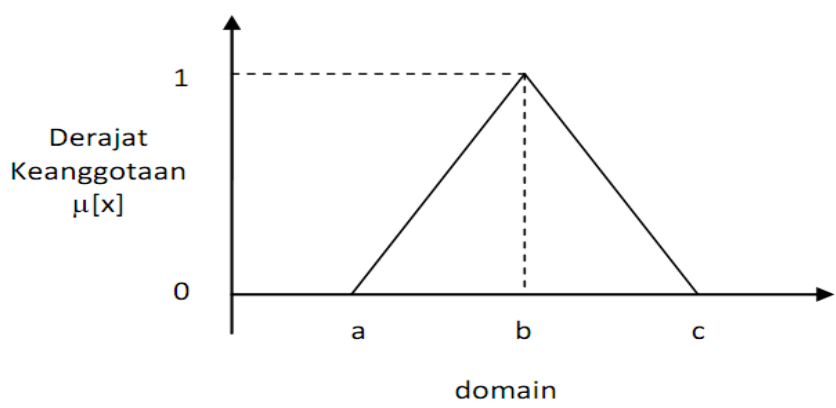

Fungsi keanggotaan :

Gambar 3. Kurva Segitiga

$$
\mu(x)= \begin{cases}0 ; & x \leq a \text { atan } x \geq c \\ (x-a) /(b-a) ; & a \leq x \leq b \\ (b-x) /(c-b) ; & b \leq x \leq c\end{cases}
$$

3) Representasi Kurva Bentuk Bahu

Daerah yang terletak di tengah-tengah suatu variabel yang direpresentasikan dalam bentuk segitiga, pada sisi kanan dan kirinya akan naik dan turun. Tetapi terkadang salah satu sisi dari variabel tersebut tidak mengalami perubahan. Himpunan fuzzy 'bahu', bukan segitiga, digunakan untuk mengakhiri variabel suatu daerah fuzzy. Bahu kiri bergerak dari benar ke salah demikian juga bahu kanan bergerak dari salah ke benar pada gambar

4. (Kusumadewi \& Purnomo, 2010).

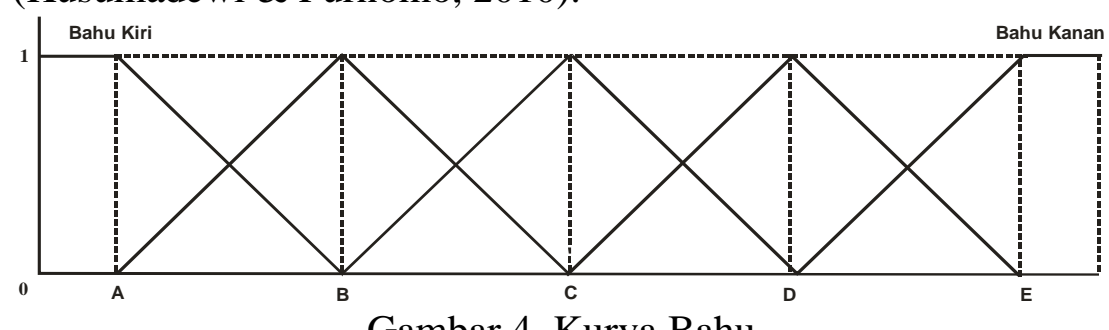

Gambar 4. Kurva Bahu

\subsection{Metode Tsukamoto}

Pada dasarnya, metode Tsukamoto mengaplikasikan penalaran monoton pada setiap aturannya. Kalau pada penalaran monoton, sistem hanya memiliki satu aturan, pada metode Tsukamoto, sistem terdiri atas beberapa aturan. Karena menggunakan konsep dasar penalaran monoton, pada metode Tsukamoto, setiap konsekuen pada aturan yang berbentuk IF-THEN harus direpresentasikan dengan suatu himpunan fuzzy dengan fungsi keanggotaan yang monoton. Output hasil inferensi dari tiap-tiap aturan diberikan secara tegas (crisp) berdasarkan $\alpha$ predikat (fire strength). Proses agregasi antar aturan dilakukan, dan hasil akhirnya diperoleh dengan menggunakan defuzzy dengan konsep rata-rata terbobot (Kusumadewi \& Purnomo, 2010).

Misalkan ada variabel masukan, yaitu $\mathrm{x}$ dan $\mathrm{y}$, serta satu variabel keluaran yaitu z. Variabel x terbagi atas 2 himpunan yaitu A1 dan A2, variabel y terbagi atas 2 himpunan juga, yaitu B1 dan B2, sedangkan variabel keluaran $\mathrm{Z}$ terbagi atas 2 himpunan yaitu $\mathrm{C} 1$ dan $\mathrm{C} 2$. Tentu saja himpunan $\mathrm{C} 1$ dan $\mathrm{C} 2$ harus merupakan himpunan yang bersifat monoton. Diberikan 2 aturan sebagai berikut: 
IF $\mathrm{x}$ is $\mathrm{A} 1$ and $\mathrm{y}$ is $\mathrm{B} 2$ THEN $\mathrm{z}$ is $\mathrm{C} 1\} \ldots \ldots \ldots \ldots \ldots$

IF $\mathrm{x}$ is $\mathrm{A} 2$ and $\mathrm{y}$ is $\mathrm{B} 1$ THEN $\mathrm{z}$ is $\mathrm{C} 2\}$

$\alpha$-predikat untuk aturan pertama dan kedua, masing-masing adalah a1 dan a2. dengan menggunakan penalaran monoton, diperoleh nilai Z1 pada aturan pertama, dan Z2 pada aturan kedua. Terakhir dengan menggunakan aturan terbobot, diperoleh hasil akhir dengan formula sebagai berikut:

Diagram blok proses inferensi dengan metode Tsukamoto dapat dilihat pada Gambar 5

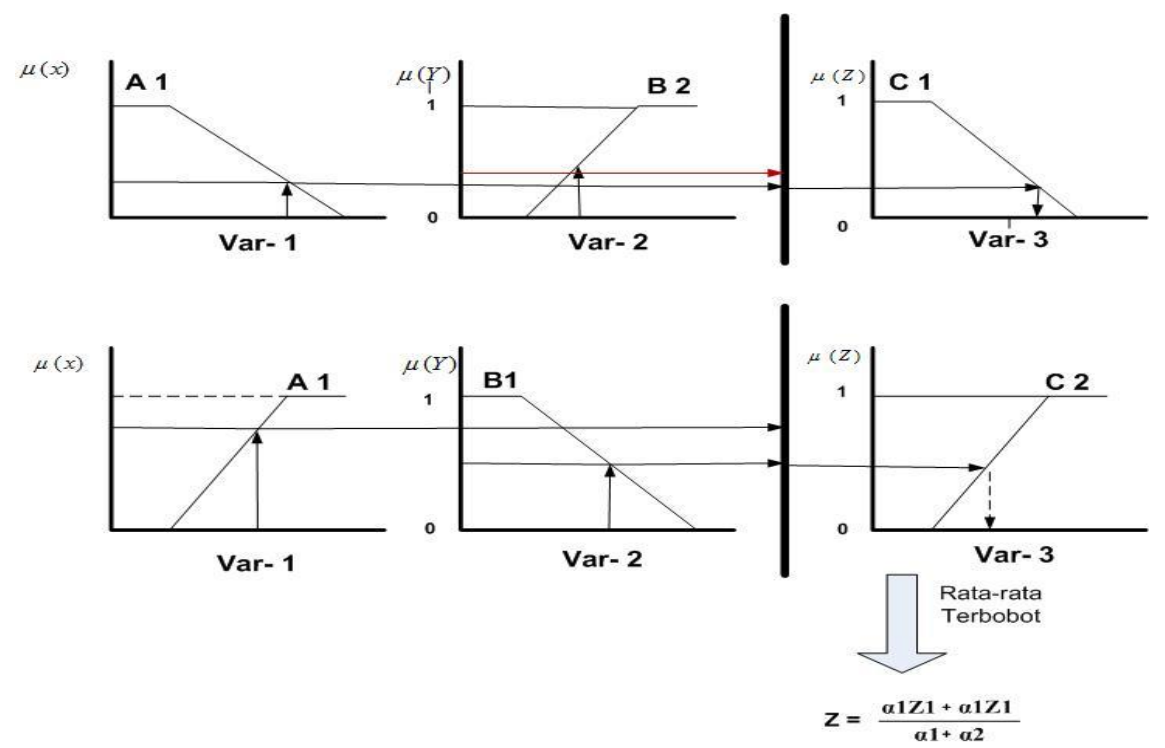

Gambar 5. Inferensi dengan menggunakan metode Tsukamoto

Terdapat dua himpunan inputan yaitu Var-1 dan Var-2. Var-3 sebagai himpunan output. Pada himpunan Var-1 Terdapat elemen A1 dan A2. Pada himpunan Var-2 terdapat elemen B1 dan B2. Yang berarti bahwa bila ada inputan yang nilainya beririsan dengan nilai A1 dan B2 maka akan dicari nilai minimum pada kedua elemen tersebut, lalu di substitusikan dengan fungsi keanggotaan dari C1 untuk mendapatkan nili z dan dilakukan defuzifikasi (Kusumadewi \& Purnomo, 2010).

\section{HASIL DAN PEMBAHASAN}

\subsection{Deskripsi Masalah Diagnosa Kanker Serviks}

Dalam proses diagnosa kanker serviks akan dibandingkan dengan menstruasi biasa yang memiliki gejala-gejala yang sama hanya saja berbeda tingkat resikonya. Parameter dalam logika fuzzy tsukamoto ini adalah data-data gejala penyakit kanker serviks, karena dalam diagnosanya akan dibandingkan dengan menstruasi biasa, maka data gejala yang diambil yang memiliki kesamaan dengan gejala atau tanda-tanda menstruasi biasa yang mempunyai kemiripan dengan ciri khasnya seperti pad Tabel 1. 
Tabel 1. Perbandingan Gejala Kanker Serviks dan Menstruasi Biasa

\begin{tabular}{|l|l|l|l|}
\hline No & Gejala & Kanker serviks & Menstruasi biasa \\
\hline 1 & Pendarahan & $\begin{array}{l}\text { Pendarahan yang abnormal } \\
\text { karena terlalu banyak dan lebih } \\
\text { dari 7 hari }\end{array}$ & $\begin{array}{l}\text { Pendarahan cenderung } \\
\text { normal sesuai siklus } \\
\text { menstruasi meski terkadang } \\
\text { berubah-ubah siklusnya }\end{array}$ \\
\hline 2 & Keputihan & $\begin{array}{l}\text { Keluar cairan yang abnormal } \\
\text { dan biasanya berbau }\end{array}$ & $\begin{array}{l}\text { Keluar cairan tetapi tidak } \\
\text { menimbulkan bau yang } \\
\text { menyengat }\end{array}$ \\
\hline 3 & Nyeri panggul & $\begin{array}{l}\text { Terjadi nyeri pada pinggang } \\
\text { bagian belakang sampai } \\
\text { panggul yang sangat } \\
\text { mengganggu }\end{array}$ & $\begin{array}{l}\text { Nyeri panggul yang } \\
\text { dirasakan cenderung } \\
\text { normal karena dirasakan } \\
\text { ketika menstruasi dan tidak } \\
\text { mengganggu }\end{array}$ \\
\hline 4 & $\begin{array}{l}\text { Penurunan } \\
\text { berat badan }\end{array}$ & $\begin{array}{l}\text { Ketika sudah masuk stadium } \\
\text { lanjut maka akan terjadi } \\
\text { penurunan bb yang sangat } \\
\text { drastis }\end{array}$ & $\begin{array}{l}\text { Tidak ada penurunan berat } \\
\text { badan pada siklus } \\
\text { menstruasi biasa. }\end{array}$ \\
\hline 5 & $\begin{array}{l}\text { Nyeri kandung } \\
\text { kemih }\end{array}$ & $\begin{array}{l}\text { Pada saat buang air kecil } \\
\text { merasakan nyeri bagian perut } \\
\text { bawah yaitu pada kandung } \\
\text { kemih dan sangat mengganggu }\end{array}$ & $\begin{array}{l}\text { Terjadi nyeri tetapi hanya } \\
\text { beberapa saat dirasakan dan } \\
\text { tidak terlalu mengganggu }\end{array}$ \\
\hline
\end{tabular}

\subsection{Deskripsi Fuzzy Infernce System Diagnosa Kanker Serviks}

FIS (Fuzzy Inference System) diagnosa kanker serviks mempunyai 5 variabel input dan 3 variabel untuk outputnya. Variabel input meliputi pendarahan, keputihan, nyeri panggul, penurunan berat badan, dan nyeri kandung kemih. Variabel output meliputi kenker serviks, cek laboratorium dan menstruasi biasa. Dalam FIS memerlukan semesta pembicaraan seperti pada tabel 2.

Tabel 2 Variabel Fuzzy

\begin{tabular}{|c|c|c|c|}
\hline Variabel & Himpunan Fuzzy & $\begin{array}{c}\text { Semesta } \\
\text { Pembicaraan }\end{array}$ & Domain \\
\hline \multirow{3}{*}{ Pendarahan } & Tidak Terjadi & \multirow{2}{*}[0-100]{} & {$[0,70]$} \\
\cline { 2 - 2 } & Kadang Terjadi & & {$[30-70]$} \\
\cline { 2 - 2 } & Abnormal & & {$[30,100]$} \\
\hline \multirow{3}{*}{ Keputihan } & Normal & \multirow{2}{*}[0-100]{} & {$[0,70]$} \\
\cline { 2 - 2 } & Kadang normal & {$[30-70]$} \\
\cline { 2 - 2 } & Abnormal & & {$[30,100]$} \\
\hline \multirow{3}{*}{ Nyeri panggul } & Tidak Terjadi & \multirow{2}{*}[0-100]{} & {$[0,70]$} \\
\cline { 2 - 2 } & Kadang Terjadi & {$[30-70]$} \\
\cline { 2 - 2 } & Terjadi & {$[30,100]$} \\
\hline \multirow{3}{*}{$\begin{array}{c}\text { Penurunan } \\
\text { berat badan }\end{array}$} & Tidak ada & & {$[0,70]$} \\
\cline { 2 - 2 } & $\begin{array}{c}\text { Ada namun tidak } \\
\text { signifikan }\end{array}$ & {$[0-100]$} & {$[30-70]$} \\
\cline { 2 - 2 } & Ada & {$[30,100]$} \\
\hline \multirow{2}{*}{$\begin{array}{c}\text { Nyeri kandung } \\
\text { kemih }\end{array}$} & Tidak Terjadi & \multirow{2}{*}[0-100]{} & {$[0,70]$} \\
\cline { 2 - 2 } & Kadang Terjadi & & {$[30-70]$} \\
\cline { 2 - 2 } & Terjadi & & {$[30,100]$} \\
\hline
\end{tabular}




\subsection{Defuzzyfikasi}

Hasil akhir diagnosa kanker serviks ini menggunakan rata-rata terbobot sebagai metode defuzzyfikasi untuk mendapatkan hasil akhir diagnosa kanker serviks. Adapun rumus rata-rata terbobot tersebut adalah sebagai berikut:

$\mathrm{Z}_{\mathrm{total}}=\frac{(\propto 1 * Z 1)+(\propto 2 * Z 2)+(\propto 3 * Z 3)+\cdots+(\propto n * Z n)}{\propto 1+\propto 2 \propto 3+\cdots+\propto n}$

Keterangan :

$\mathrm{Z}=$ hasil diagnosa kanker serviks

$\propto n=$ Derajat Keanggotaan dari aturan ke- $\mathrm{n}$

$\mathrm{zn}=$ nilai dari aturan ke-n

\subsection{Fungsi Fuzzy}

Berdasarkan dari input gejala diatas, maka didapat fungsi fuzzynya sebagai berikut:

a. Variabel Pendarahan

$\mu$ pendarahan tidak terjadi $\mu$ kadang-kadang terjadi $=\left\{\begin{array}{cc}1 ; & x \leq 30 \\ \frac{70-x}{40} & 30 \leq x \leq 70 \\ 0 ; & x \geq 70 \\ 0 ; & x \leq 30 \\ \frac{x-30}{20} & 30 \leq x \leq 50 \\ \frac{70-x}{20} & 50 \leq x \leq 70 \\ 1 ; & x \geq 70 \\ 0 ; & x \leq 30 \\ \frac{x-30}{40} & 30 \leq x \leq 70 \\ 1 ; & x \geq 70\end{array}\right.$

b. Variabel Keputihan

$\mu$ keputihan normal $=\left\{\begin{array}{cc}1 ; & x \leq 30 \\ \frac{70-x}{40} & 30 \leq x \leq 70 \\ 0 ; & x \geq 70 \\ 0 ; & x \leq 30 \\ \frac{x-30}{20} & 30 \leq x \leq 50 \\ \frac{70-x}{20} & 50 \leq x \leq 70 \\ 1 ; & x \geq 70 \\ 0 ; & x \leq 30 \\ \frac{x-30}{40} & 30 \leq x \leq 70 \\ 1 ; & x \geq 70\end{array}\right.$


c. Variabel Nyeri Panggul

$$
\mu \text { nyeri panggul tidak terjadi } \quad \mu \text { kadang-kadang terjadi }=\left\{\begin{array}{cc}
1 ; & x \leq 30 \\
\frac{70-x}{40} & 30 \leq x \leq 70 \\
0 ; & x \geq 70 \\
0 ; & x \leq 30 \\
\frac{x-30}{20} & 30 \leq x \leq 50 \\
\frac{70-x}{20} & 50 \leq x \leq 70 \\
1 ; & x \geq 70 \\
0 ; & x \leq 30 \\
\frac{x-30}{40} & 30 \leq x \leq 70 \\
1 ; & x \geq 70
\end{array}\right.
$$

d. Variabel Penurunan Berat Badan

$$
\begin{aligned}
& \begin{array}{l}
\mu \text { tidak ada penurunan } \\
\text { berat badan }
\end{array}=\left\{\begin{array}{cc}
1 ; & x \leq 30 \\
\frac{70-x}{40} & 30 \leq x \leq 70 \\
0 ; & x \geq 70
\end{array}\right. \\
& \begin{array}{l}
\mu \text { ada penurunan namun } \\
\text { tidak signifikan }
\end{array}=\left\{\begin{array}{cc}
0 ; & x \leq 30 \\
\frac{x-30}{20} & 30 \leq x \leq 50 \\
\frac{70-x}{20} & 50 \leq x \leq 70 \\
1 ; & x \geq 70 \\
0 ; & x \leq 30 \\
\text { badan penurunan berat } & 30 \leq x \leq 70 \\
\frac{x-30}{40} & x \geq 70 \\
1 ; &
\end{array}\right.
\end{aligned}
$$

e. Variabel Nyeri Kandung Kemih

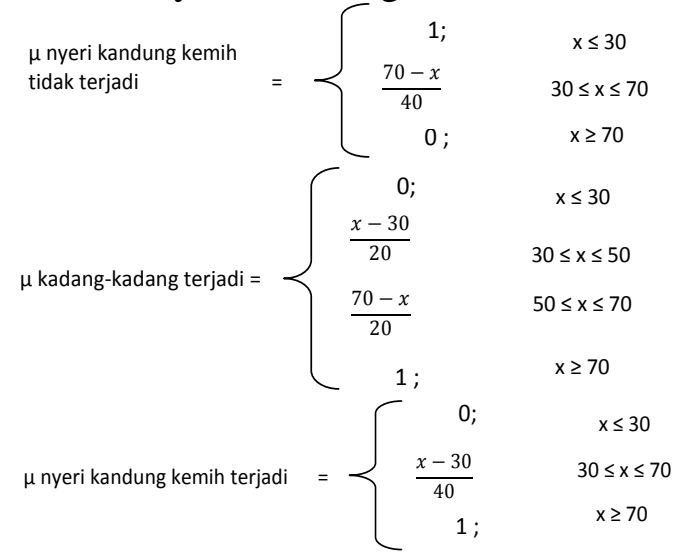

\subsection{Contoh Kasus}

Seorang pasien mengalami gejala sebagai berikut: tidak ada keluhan pendarahan, keputihan normal, tidak nyeri panggul, tidak ada penurunan berat badan dan tidak merasakan nyeri pada kandung kemih.

Setelah dilakukan inferensi untuk setiap hipotesa penyakit menggunakan metode Tsukamoto, beradasarkan aturan yang berkaitan, maka hasil dari prediksi penyakit terlihat pada Tabel 3. 
Tabel 3. Contoh Kasus

\begin{tabular}{|l|l|l|}
\hline No. & penyakit & Prosentase \\
\hline 1 & Menstruasi biasa & 56,25 \\
\hline 2 & Cek laboratorium & 43,75 \\
\hline 3 & Kanker Serviks & 0 \\
\hline
\end{tabular}

Berdasarkan hasil yang diperoleh, dapat disimpulkan bahwa pasien hanya mengalami siklus menstruasi biasa dengan prosentase $56,25 \%$.

\subsection{Perancangan Sistem}

\subsubsection{Diagram Konteks}

Diagram konteks dari aplikasi sistem pakar diagnosa penyakit kanker serviks menggunakan metode Fuzzy ditunjukkan pada Gambar 6.

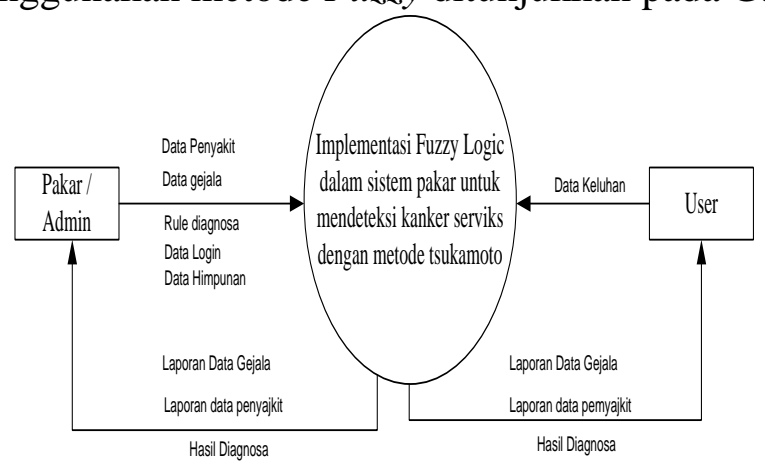

Gambar 6. Diagram Konteks

Entitas eksternal (External entity) yang terlibat dalam sistem adalah Pakar dan User dengan Sistem Pakar Untuk Diagnosa Penyakit Mata Pada Manusia Menggunakan Metode Fuzzy sebagai intinya. Aliran data yang berasal dari Pakar adalah data penyakit, data gejala, dan rule diagnosa, sedangkan aliran data yang berasal dari user adalah data keluhan. Sistem selanjutnya menanggapi masukan dari user dengan keluaran berupa hasil diagnosa.

\subsubsection{Entity Relationship Diagram dan Relasi Tabel}

Adapun rancangan ERD untuk sistem pakar diagnosa kanker serviks bisa dilihat pada Gambar 7 sedangkan relasi tabel ditunjukkan pada Gambar 8 .

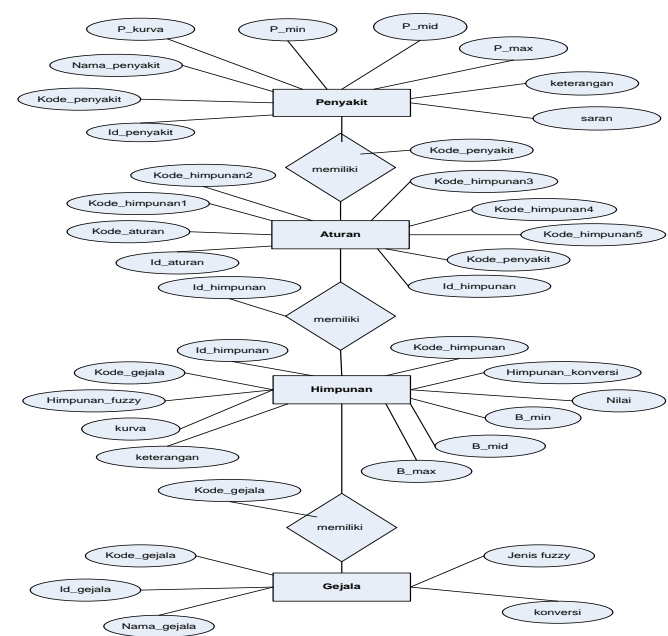

Gambar 7. Entity Relationship Diagram 


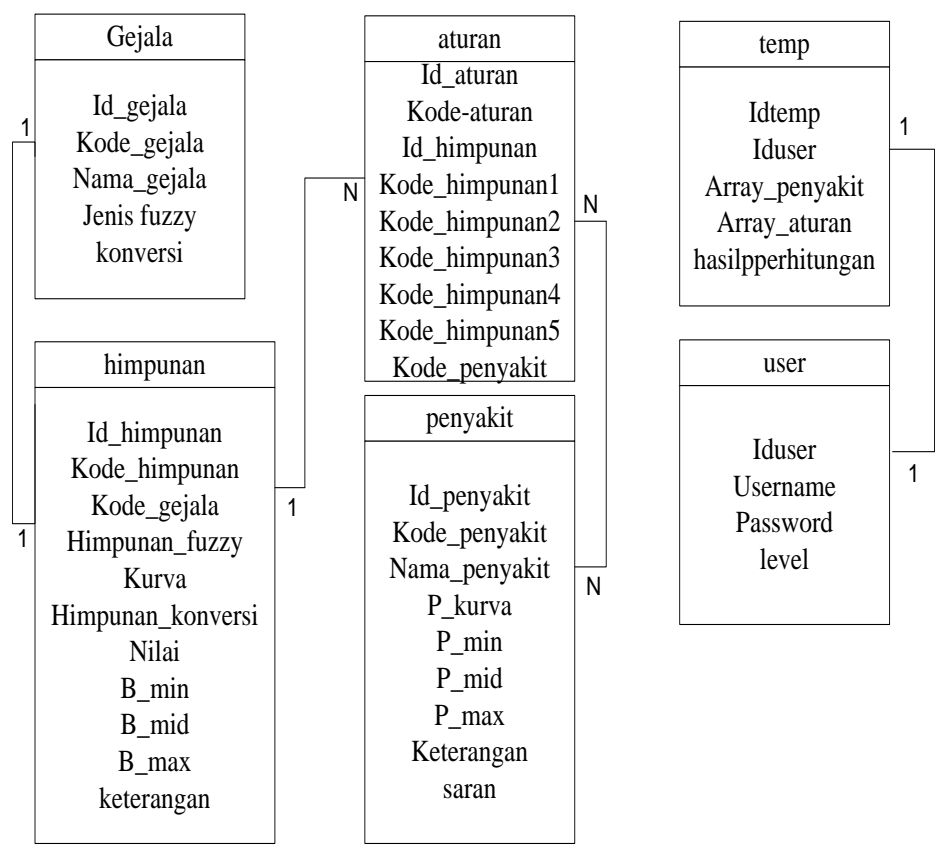

Gambar 8. Relasi Tabel

\subsubsection{Implementasi Sistem}

Pada gambar diatas terdapat beberapa menu yang dapat diakses oleh user antara lain: deskripsi kanker serviks, diagnosa penyakit, dan login sistem.

1. Halaman diagnosa penyakit

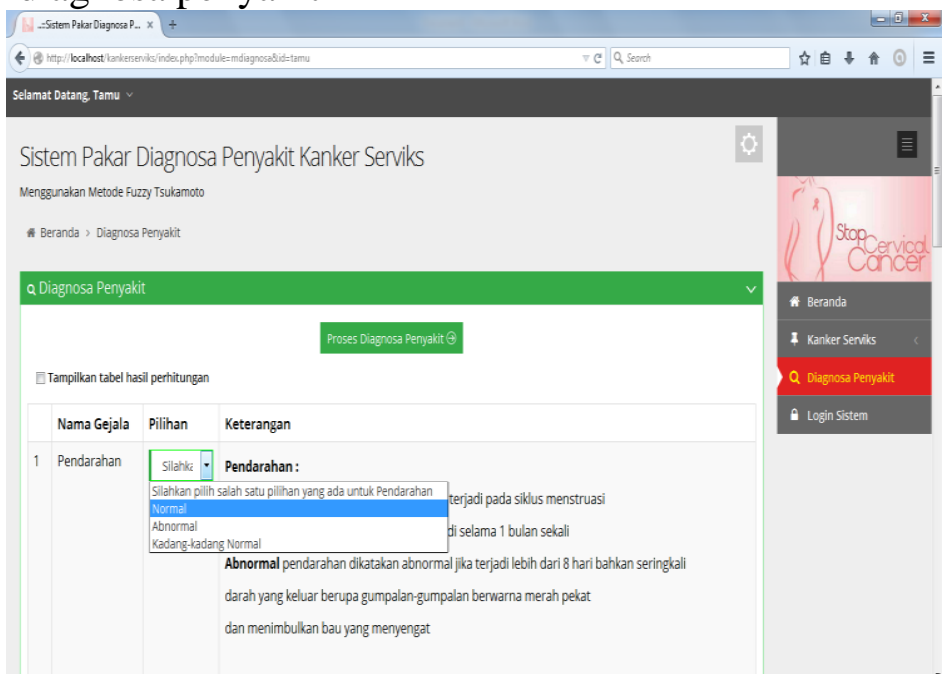

Gambar 9. Halaman Diagnosa Penyakit

Dalam halaman diagnosa penyakit, user dapat melakukan input data gejala dengan pilihan yang telah ditampilkan oleh sistem yang nantinya digunakan untuk mendiagnosa penyakit. Pada masing-masing gejala atau variabel terdapat keterangan-keterangan yang dapat membantu 
user untuk memahami deksripsi maupun batasan dari suatu gejala atau variabel.

2. Halaman hasil diagnosa penyakit

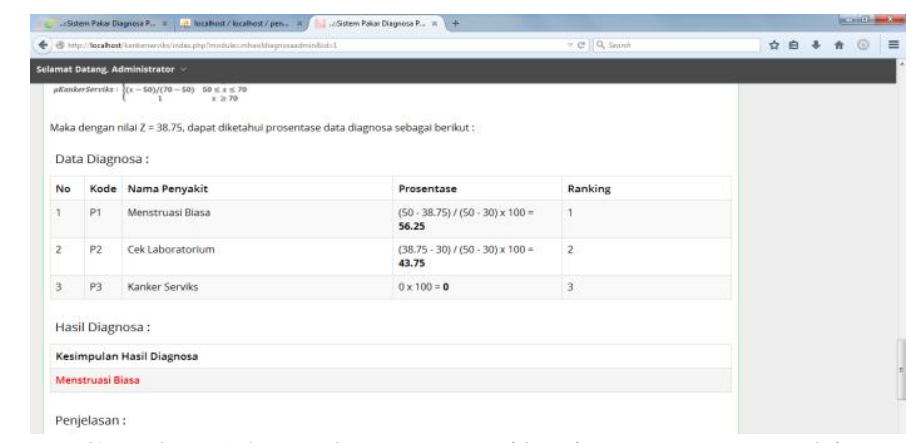

Gambar 10. Halaman Hasil Diagnosa Penyakit

Pada halaman hasil diagnosa penyakit, user dapat mengetahui hasil prediksi penyakit sesuai dengan input gejala atau variabel yang telah diinputkan sebelumnya pada halaman diagnosa penyakit. Dalam halaman hasil diagnosa, terdapa tempat pokok penting yang harus diperhatikan yaitu tabel gejala yang telah diiputkan, prediksi penyakit yang ditawarkan, deskripsi dari penyakit yang memiliki prosentase terbesar, dan saran yang dianjurkan.

\subsubsection{Pengujian}

Pengujian dilakukan dengan membandingkan hasil perhitungan dari rule yang ada di sistem dengan hasil diagnosa dari pakar. Pengujian ini menggunakan 10 kasus. Berdasarkan perbandingan antara hasil diagnosa dari perhitungan rule yang ada di sistem dengan hasil diagnosa dari pakar adalah sebagai berikut:

Tingkat valid sistem $=($ jumlah data akurat/total sampel $) * 100 \%$

$=(8 / 10) * 100 \%$

$=80 \%$

Hasil pengujian menunjukkan implementasi dari logika fuzzy dalam sistem pakar untuk mendeteksi penyakit kanker serviks telah bekerja dengan baik.

\section{KESIMPULAN DAN SARAN}

\subsection{Kesimpulan}

Dalam pembuatan dan penyelesaian tugas akhir yang berjudul "Implementasi Fuzzy Logic dalam Sistem Pakar untuk Mendeteksi Peyakit Kanker Serviks" ini dapat ditarik kesimpulan bahwa logika fuzzy dapat diimplementasikan dalam sistem pakar untuk mendeteksi penyakit kanker serviks dengan input berbagai gejala penyakit sehingga memperoleh output yang berupa prosentase resiko penyakit tentunya setelah melalui tahap perhitungan menggunakan Fuzzy Inference System dan hasil perbandingan hasil perhitungan sistem dengan hasil diagnosa pakar senilai $80 \%$ keakurasiannya. 


\subsection{SARAN}

Penulis memberikan saran yang mungkin bermanfaat bagi pengembangan tugas akhir ini antara lain:

1. Penyakit yang dibahas dalam sistem pakar ini dibatasi hanya kanker serviks untuk kedepannya dapat ditambahkan data penyakit dan gejala serta pengetahuan kepakaran lebih banyak agar dapat digunakan lebih luas lagi.

2. Diharapkan kedepannya bisa menggunakan metode-metode lain.

\section{DAFTAR PUSTAKA}

FKUI. (2002). Deteksi Dini Kanker. Jakarta: FKUI.

Kusumadewi, S., \& Purnomo. (2010). Aplikasi Logika Fuzzy Untuk Pendukung Keputusan. Yogyakarta: Graha Ilmu.

Novel, S. S., Nusantara, S., \& Safitri, R. (2010). Kanker Serviks dan Infeksi Human Papillomavirus (HPV). Jakarta Selatan: Java Media Network.

Siswanto. (2010). Kecerdasan Tiruan. Yogjakarta: Graha Ilmu.

Sutojo, T., Mulyanto, E., \& Suhartono, V. (2011). Kecerdasan Buatan. Yogyakarta: Andi. 